\title{
STRATEGI SOSIALISASI KEBIJAKAN PENDEREKAN OLEH SUKU DINAS PERHUBUNGAN JAKARTA BARAT
}



Diterima 1 Januari 2019

Disetujui 26 Februari 2019 


\section{PENDAHULUAN}

Pemandangan sepeda motor berjejer terlihat di sepanjang jalan Kembangan Raya, depan kantor Kejaksaan Negeri Jakarta Barat. Puluhan motor tampak berjejer parkir secara sembarangan dibahu jalan (Novian Ardiansyah, https://jakarta. tribunnews.com/2018/11/23/trotoar-depankejaksaan-negeri-jakarta-barat-digunakan- di-perumahan;2017). Dikarenakan banyak sekali petugas derek sering menemukan pelanggar di kawasan perumahan. Hal itu karena mereka tidak memiliki garasi mobil untuk menyimpan mobil. Bahkan yang lebih parah pelanggaran parkir di perumahan, perkantoran, dan sekolah.

Dengan adanya kasus parkir liar yang nampak terjadi di wilayah Jakarta Barat. Sebenarnya peraturan tidak diperbolehkan parkir di badan

Tabel 1.

Jumlah Kendaraan Angkutan Umum dan Barang Diderek Suku Dinas Perhubungan dan Transportasi Kota Administrasi Jakarta Barat

\begin{tabular}{|c|c|c|c|c|}
\hline No & Bulan di Tahun 2018 & $\begin{array}{c}\text { Jumlah Kendaraan yang di- } \\
\text { derek Pada Tahun 2018 }\end{array}$ & Jenis Tindakan & Jenis Pelanggaran \\
\hline 1 & Januari 2018 & 454 Kendaraan & DIDEREK & Parkir di badan Jalan \\
\hline 2 & Februari 2018 & 367 Kendaraan & DIDEREK & Parkir di badan Jalan \\
\hline 3 & Maret 2018 & 516 Kendaraan & DIDEREK & Parkir di badan Jalan \\
\hline 4 & April 2018 & 420 Kendaraan & DIDEREK & Parkir di badan Jalan \\
\hline 5 & Mei 2018 & 332 Kendaraan & DIDEREK & Parkir di badan Jalan \\
\hline 6 & Juni 2018 & 148 Kendaraan & DIDEREK & Parkir di badan Jalan \\
\hline 7 & Juli 2018 & 368 Kendaraan & DIDEREK & Parkir di badan Jalan \\
\hline 8 & Agustus 2018 & 50 Kendaraan & DIDEREK & Parkir di badan Jalan \\
\hline 9 & September 2018 & 265 Kendaraan & DIDEREK & Parkir di badan Jalan \\
\hline 10 & Oktober 2018 & 335 Kendaraan & DIDEREK & Parkir di badan Jalan \\
\hline 11 & November 2018 & 441 Kendaraan & DIDEREK & Parkir di badan Jalan \\
\hline 12 & Desember 2018 & 461 Kendaraan & DIDEREK & Parkir di badan Jalan \\
\hline
\end{tabular}

(Sumber: Lamudin, Pengawas Suku Dinas Perhubungan Jakarta Barat, 2018)

oknumjadi-lahan-parkir-liar?page $=3: 2018)$. Tidak hanya sepeda motor yang terlihat berjejer parkir sembarangan di bahu jalan namun kendaraan roda empat tampak parkir di badan jalan atau di atas trotoar. Data yang direkap oleh Suku Dinas Perhubungan Jakarta Barat pada tahun 2018 tercatat sejumlah 4.157 kendaraan roda empat yang diderek dengan jenis pelanggaran yaitu parkir dibadan jalan (Lamudin, Pengawas Suku Dinas Perhubungan Jakarta Barat, 2019).

Terdapat delapan titik wilayah yang sudah dipetakan oleh Suku Dinas Perhubungan Jakarta Barat yang merupakan wilayah rawan mobil parkir di bahu jalan antara lain Pasar Sentra di Cengkareng, Jalan S Parman dari Taman Anggrek sampai Grogol, Kalijodo sampai Season City, Jalan Gajah Mada. Jalan Panjang, Jalan Bali di Palmerah, Pesanggrahan, dan Terminal Kalideres (Ikhsanuddin, https://news.detik.com/berita/d-3681801/ada8-lokasi-rawan-parkir-liar-di-jakbar-kebanyakan- jalan sudah diatur di dalam Peraturan Daerah DKI Jakarta Nomor 5 Tahun 2014 tentang Transportasi. Dengan adanya Perda tersebut khususnya di Ibu Kota DKI Jakarta sudah mempunyai "Payung Hukum" dan terhindar dari kemacetan lalu lintas untuk mematuhi peraturan. Bagi pemerintah, dengan adanya peraturan Perda tersebut menjadi alat bantu untuk mengurangi kemacetan lalu lintas dan parkir liar di lingkungan DKI Jakarta. Pemerintah melakukan langkah-langkah nyata untuk mengurangi kemacetan lalu lintas dan mengurangi adanya parkir liar di bahu jalan dengan cara kendaraan angkutan umum dan barang diderek sedangkan kendaraan roda dua dengan cara pencabutan pentil. Agar masyarakat jera tidak melakukan parkir di badan jalan.

Kegiatan sosialisasi ini merupakan aktivitas yang dilakukan Suku Dinas Perhubungan Jakarta Barat dengan pembentukan tim penderekan dan penindakan yang melibatkan unsur pemerintahan, 
perguruan tinggi dan masyarakat sekitar. Sosialisasi Perda tersebut merupakan langkah awal supaya masyarakat tidak melakukan pelanggaran lalu lintas dan melakukan parkir liar di bahu jalan dan menjadi upaya preventif untuk pencegahan dini pemahaman berkendara. Situasi sosial sekarang ini tidak terlepas dari Sistem Peraturan Transportasi di Indonesia yang di atur di dalam Peraturan Daerah DKI Jakarta Nomor 5 Tahun 2014. Membahas dan mempertimbangkan mengenai sistem transportasi untuk mewujudkan transportasi yang handal sesuai dengan kedudukan dan kewenangan Provinsi Daerah Khusus Ibu Kota Jakarta yang publikasi di dalam Web Dinas Perhubungan DKI Jakarta. Konteks mengenai peraturan transportasi menjadi tanggung jawab Dinas Perhubungan menderek kendaraan yang nekat untuk tetap parkir pada lahan yang bukan diperuntukkan sebagai lahan parkir. Polemik yang terjadi adalah ketika peraturan tersebut digulirkan, bahkan sudah diterapkan, masih terdapat pengguna kendaraan roda empat yang merasa belum mengetahui perda tersebut. Sehingga ketika dilakukan penderekan, pengendara melakukan perlawanan. Padahal pihak Dinas Perhubungan sudah melakukan sosialisasi mengenai peraturan tersebut baik dalam media sosial, ke Masyarakat bahkan ke Perguruan Tinggi yang terdapat di wilayah Jakarta Barat.

Adanya sosialisasi mengenai penderekan seyogyanya mengikuti prinsip-prinsip yaitu adanya penghormatan dan menghargai sesama pengguna pengendara kendaraan, adanya penghormatan

Tabel 2.

Jumlah Kendaraan Roda Empat Tahun 2009 sampai dengan Tahun 2016

\begin{tabular}{|c|c|c|c|c|c|c|c|c|}
\hline $\begin{array}{c}\text { Jenis } \\
\text { Kendaraan }\end{array}$ & Tahun 2009 & Tahun 2010 & Tahun 2011 & Tahun 2012 & Tahun 2013 & Tahun 2014 & Tahun 2015 & Tahun 2016 \\
\hline $\begin{array}{c}\text { Mobil } \\
\text { Penumpang }\end{array}$ & 7.910 .407 & 8.891 .041 & 9.548 .866 & 10.432 .259 & 11.484 .514 & 12.599 .038 & 13.480 .973 & 14.580 .666 \\
\hline $\begin{array}{c}\text { Mobil } \\
\text { Bis }\end{array}$ & 2.160 .973 & 2.250 .109 & 2.254 .406 & 2.273 .821 & 2.286 .309 & 2.398 .846 & 2.420 .917 & $2,486.898$ \\
\hline $\begin{array}{c}\text { Mobil } \\
\text { Barang }\end{array}$ & 4.498 .171 & 4.687 .789 & 4.687 .789 & 5.286 .061 & 5.615 .494 & 6.235 .136 & 6.611 .028 & 7.063 .433 \\
\hline
\end{tabular}

(Sumber: Badan Pusat Statistik (2018) https://www.bps.go.id/linkTableDinamis/view/id/1133)

disetiap masing-masing provinsi di negara Republik Indonesia.

Badan Pusat Statistik, melihat perkembangan jumlah kendaraan roda empat dan roda dua di tahun 2009 sampai 2016 mengalami kenaikan yang signifikan. Kendaraan roda empat dibagi menjadi 3 jenis mobil yaitu mobil penumpang, mobil bis dan mobil barang. Jumlah mobil penumpang di tahun 2009 sejumlah 7.910.407 kendaraan sedangkan di tahun 2016 sejumlah 14580666. Kendaraan lainnya seperti Mobil Bis sejumlah 2.160.973 kendaraan di tahun 2009, sedangkan di tahun 2016 sejumlah 2.486.896 kendaraan. Untuk jenis mobil barang di tahun 2009 berjumlah 4.498.171 kendaraan, sedangkan ditahun 2016 berjumlah 7.063 .433 kendaraan.

Semakin tingginya jumlah pengguna kendaraan di Jakarta, berbanding lurus dengan meningkatnya kebutuhan lahan parkir kendaraan. Peraturan tidak boleh parkir di badan jalan dan di trotoar sudah diatur dalam Undang-Undang Nomor 22 Tahun dan pengakuan terhadap hak dan martabat manusia, kepastian hukum atas pelanggaran terhadap kendaraan parkir pada lahan yang bukan diperuntukkan sebagai lahan parkir.

Tujuan sosialiasi mengenai penderekan agar masyarakat paham dan patuh terhadap peraturan tidak boleh parkir kendaraan di bahu jalan, badan jalan, trotoar yang menimbulkan kemacetan lalu lintas. Selain itu, terciptanya masyarakat paham apabila tidak adanya simbol rambu lalu pintas $\mathbf{P}$ berwarna biru di jalan raya maaupun di pemukiman perumahan, perkantoran dan sekolah dimaknakan tidak boleh parkir. Simbol Lalu Lintas $\mathrm{P}$ berwarna biru terlihat di bawah ini : 
Gambar 1.

\section{Rambu Lalu Lintas Parkir}

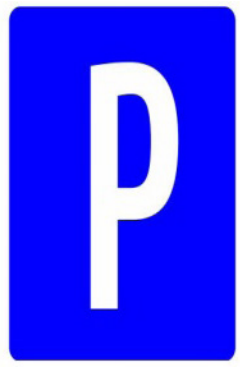

Selain itu, adanya tujuan sosialisasi ini agar tercapai sebuah strategi yang tepat dalam mengkomunikasi kebijakan tersebut ke masyarakat. Sebaik-baiknya sebuah kebijakan adalah yang diketahui, dipahami dan diimplementasikan oleh target sasarannya. Oleh karena itu, penelitian ini berusaha untuk mengungkap strategi sosialisasi kebijakan penderekan oleh Suku Dinas Perhubungan Jakarta Barat, melalui perspektif studi kasus.

\section{TINJAUAN PUSTAKA}

\section{Teori Manajemen Komunikasi}

Dalam teori Manajemen Komunikasi, Michael Kaye mengatakan, "Di mana individu atau manusia mengelola proses komunikasi melalui penyusunan kerangka makna dalam hubungannya dengan orang lain dalam berbagai lingkup komunikasi dengan mengoptimalisasi sumberdaya komunikasi dan teknologi yang ada" (Marroli J. Indarto. 2012:36). Adanya proses penggunaan berbagai sumberdaya komunikasi secara terpadu melalui proses perencanaan, pengorganisasian, pelaksanaan dan pengontrolan unsur-unsur komunikasi untuk mencapai tujuan yang telah ditetapkan (Parag Diwan, 1999). Jadi, Pengaplikasian penggunaan sumberdaya manusia dan teknologi secara optimal untuk meningkatkan dialog diantara manusia (Egan dan Cowan, 1997).

Definisi Manajemen Komunikasi adalah proses pengelolahan Sumber Daya Komunikasi yang ditujukan untuk meningkatkan kualitas dan efektivitas pertukaran pesan yang terjadi dalam berbagai konteks komunikasi (individual, organisasional, govermental, sosial, atau internasional). Manajemen tersebut meliputi perencanaan sebuah aktifitas, pengorganisasian, penggerakkan, serta evaluasi yang dilakukan setiap saat. Melalui manajemen yang baik inilah, sebuah strategi program dijalankan (Andi
Fachrudin, 2014:137). Menurut Shimp komunikasi merupakan sebuah proses di mana pemikiran dan pemahaman disampaikan antar individu, atau antara organisasi dengan indvidu (Dian Sarastuti, 2017: 71-90).

Baker dalam Claywood (1997:461-463) mengatakan manajemen komunikasi pemerintah secara taktikal meliputi tiga hal: Pertama, identifikasi isu secara fokus menyangkut kebijakan atau program pemerintah. Kedua, menyusun perencanaan komunikasi mengacu pada isu yang sudah dikemas sesuai karakteristik yang diinginkan. Ketiga, mengeksekusi perencanaan komunikasi.

Berdasarkan teori pemangku kepentingan Guthrine et al, 2004 dalam Erwansyah, 2009 menyatakan bahwa manajemen perusahaan diharapkan untuk dapat melakukan aktivitas sesuai yang diharapakan pemangku kepentingan dan melaporkannya kepada mereka. Teori ini menyatakan bahwa para pemangku kepentingan memiliki hak untuk mengetahui semua informasi baik informasi mandatory (karena legalitas) maupun voluntary (sukarela). Dampak aktivitas perusahaan kepada pemangku kepentingan dapat diketahui melalui pertanggungjawaban yang diberikan perusahaan berupa informasi keuangan dan non keuangan (sosial).

Terdapat dua postur strategis yang akan diadopsi perusahaan. Bersikap aktif (active posture), merupakan strategi yang berusaha mempengaruhi hubungan organisasi dengan pemangku kepentingan yang dipandang berpengaruh atau penting. bersikap pasif (passive posture). Strategi yang cenderung tidak terus menerus memonitor aktivitas pemangku kepentingan dan secara sengaja tidak mencari strategi optimal untuk menarik perhatian mereka. Kurangnya perhatian terhadap pemangku kepentingan akan mengakibatkan rendahnya tingkat pengungkapan informasi sosial dan rendahnya kinerja sosial perusahaan.

\section{Teori Perencanaan}

Perencanaan merupakan proses dasar di mana manajemen memutuskan tujuan dan cara pencapaiannya (Ais Zakiyudin, 2016:29). Perencanaan terjadi disemua tipe kegiatan. Perencanaan dalam organisasi merupakan suatu kegiatan yang esensial, karena memang fungsi-fungsi manajemen yang lain seperti pengorganisasian, pengarahan dan pengawasan sebenarnya merupakan implementasi dari keputusan keputusan perencanaan. Beberapa 
definisi perencanaan yang dijelaskan, Samuel Certo menyatakan bahwa "Proses penentuan bagaimana sistem manajemen (organisasi) akan mencapai atau merealisasikan tujuannya".

Proses perencanaan menggambarkan serangkaian langkah-langkah yang dapat dilalui secara sistematis. Setiap tahap perencanaan selalu meliputi empat tahapan (Ais Zakiyudin, 2016:29)., antara laun : 1 . Menetapkan sasaran atau tujuan. Tujuan atau sasaran berlaku agar perencanaan tersebut bisa tercapai. Apabila perencanaan dibuat tanpa menentukan tujuan, maka rencana dan sumber daya manusia tidak terarahkan., 2. Merumuskan keadaan saat ini. Seorang pemimpin hendaknya mengetahui kondisi di dalam organisasi tersebut. Kondisi organisasi mulai dari keuangan, data SDM, data statistik dan sebagainya. Bertujuan agar rencana yang akan dibuat dengan kondisi organisasi tersebut seimbang. Sehubungan dengan perencanaan adalah waktu yang akan dicapai di masa yang akan datang., 3. Membuat alternatif. Merupakan cara-cara untuk mencapai tujuan yang sudah ditetapkan oleh organisasi., 4. Mengidentifikasi kemudahan dan hambatan. Untuk mengukur tingkat kemampuan organisasi lain dalam mencapai tujuan., 5. Mengembangkan rencana. Merupakan tahap akhir dalam mengembangkan berbagai cara untuk mencapai tujuan atau sasaran.

\section{Analisis SWOT}

Analisis SWOT (SWOT analysis) yakni mencakup upaya-upaya untuk mengenali kekuatan, kelemahan, peluang, dan ancaman yang menentukan kinerja perusahaan. Informasi eksternal mengeni peluang dan ancaman dapat diperoleh dari banyak sumber, termasuk pelanggan, dokumen pemerintah, pemasok, kalangan perbankan, rekan diperusahaan lain. Di mana banyak jasa lembaga, pemindaian untuk memperoleh keliping surat kabar, riset diinternet dan lain lain (Richard L. Daft 2010:253).

Fredi Rangkuti (2004: 18) menjelaskan bahwa Analisis SWOT adalah identifikasi berbagai faktor secara sistematis untuk merumuskan strategi perusahaan. SWOT merupakan alat yang dipakai untuk menyusun faktor-faktor strategis perusahaan. Matrik ini dapat mengambarkan secara jelas bagaimana peluang dan ancaman eksternal yang dihadapi perusahaan dapat disesuaikan dengan kekuatan dan kelemahan yang dimilikinya.

\section{Sosialisasi}

Sosialisasi, menurut Effendy adalah penyediaan sumber ilmu pengetahuan yang memungkinkan orang bersikap dan bertindak sebagi anggota masyarakat yang efektif yang menyebabkan ia sadar akan fungsi sosialnya sehingga ia dapat aktif di dalam masyarakat (Effendy, 1999:27). Proses sosialisasi ini terjadi melalui interaksi sosial, yaitu hubungan antar manusia yang menghasilkan suatu proses pengaruh-mempengaruhi (Susanto, 1999:13). Suatu interaksi sosial tidak akan mungkin terjadi apabila tidak memenuhi dua syarat, yaitu: (1) kontak sosial dan (2) komunikasi. Oleh karenanya, di dalam proses sosialisasi selalu terjadi proses komunikasi (Soekanto, 1989:71).

Komunikasi yang berkaitan dengan proses sosialisasi adalah komunikasi sosial. Komunikasi sosial merupakan suatu proses sosialisasi untuk menciptakan pencapaian stabilitas sosial, tertib sosial, penerusan nilai-nilai lama dan baru yang diagungkan oleh suatu masyarakat dipupuk, dibina dan diperluas. Melalui komunikasi sosial, masalahmasalah sosial dipecahkan melalui konsensus (Bungin, 2007:32). Tak jarang pula sosialisasi dilakukan untuk memperkenalkan gagasan-gagasan kepada masyarakat dengan asumsi bahwa masyarakat tersebut tidak mengetahui gagasan tersebut secara pasti. Kebaruan suatu ide atau gagasan tidaklah selamanya benar-benar baru, melainkan hanya karena dianggap baru oleh penerima (Arifin, 1994:10). Effendy (1999:21) mengatakan komunikasi pada hakikatnya adalah proses penyampaian pikiran,atau perencanaan atau perasaan oleh seseorang (komunikator) kepada orang lain (komunikan).

Pikiran bisa merupakan gagasan, informasi, opini dan lain-lain yang muncul dari benaknya. Perasaan bisa berupa keyakinan, kepastian, keraguan, kekhawatiran, kemarahan keberanian, kegairahan dan sebagainya yang timbul dari lubuk hati (Bungin, 2007:31). Effendy (1999:32), strategi komunikasi merupakan panduan perencanaan komunikasi (communication planning) dengan manajemen komunikasi (communication management) untuk mencapai tujuan yang telah ditetapkan. Strategi komunikasi ini harus mampu menunjukan bagaimana operasionalnya 
secara praktis harus dilakukan, dalam arti kata bahwa pendekatan (approach) bisa berbeda-beda bergantung pada situasi dan kondisi.

Sedangkan Arifin mendefinisikan strategi komunikasi sebagai suatu perencanaan komunikasi yang meliputi strategi dan manajemen perencanaan strategi menyangkut tindakan apa yang dilakukan, sedangkan perencanaan meliputi bagaimana hal-hal itu terjadi (Arifin, 1994:10). Perubahan merupakan hasil proses komunikasi yang tidak mungkin dielakan. Semua pihak berkomunikasi, mau tidak pasti mengalami perubahan, baik perubahan kecil maupun perubahan besar. Bahkan komunikasi dapat merubah sama sekali citra seseorang atau kelompok mengenai dirinya sendiri maupun mengenai lingkungannya. Itulah sebabnya komunikasi memiliki kedudukan yang sangat strategis dalam keseluruhan perubahan masyarakat atau perubahan sosial. Strategi komunikasi digunakan tidak cukup hanya dalam tahap kesadaran (awareness), tetapi bagi tahap-tahap komunikasi lainnya, yaitu perubahan sikap (attitude change) dan perubahan perilaku (behaviour changes) pada seseorang atau lebih individu.

\section{Strategi Komunikasi}

Komunikasi erat hubungannya antara tujuan yang hendak dicapai dengan konsekuensi-konsekuensi (masalah) yang harus diperhatikan, kemudian merencanakan Strategi bagaimana konsekuensikonsekuensi sesuai dengan hasil yang diharapkan atau tujuan yang akan dicapai. Strategi pada hakikatnya adalah suatu perencanaan (planning) dan manajemen (management) untuk mencapai suatu tujuan. Akan tetapi, untuk mecapai tujuan tersebut, strategi tidak berfungsi sebagai peta jalan yang hanya menunjukkan arah saja, melainkan harus mampu menunjukkan bagaimana taktik operasionalnya.

James Brian Quin menjelaskan dalam bukunya yang berjudul Strategies For Change: Logical Incrementalism, memberikan definisi strategi yaitu "Strategi merupakan suatu bentuk atau rencana yang mengintegrasikan tugas-tugas utama, kebijakankebijakan dan rangkaian tindakan dalam suatu organisasi menjadi suatu kesatuan yang utuh. Strategi yang diformulasikan dengan baik akan membantu penyusunan dan pengalokasian sumber daya yang dimiliki perusahaan menjadi suatu bentuk yang unik dan dapat bertahan. Strategi yang baik disusun berdasarkan kemampuan internal dan kelemahan perusahaan, antisipasi perubahan dalam lingkungan, serta kesatuan pergerakan yang dilakukan oleh matamata musuh (Quinn, 1980:10. Ebook).

Komunikasi berkembang sejalan dengan perkembangan masyarakat, mulai dari masyarakat kecil dalam bentuk keluarga sampai masyarakat besar seluas dengan negara dan, dan sebagainya. Komunikasi tidak lagi merupakan upaya agar seseorang seluas dunia. Effendi (1999:21) mengatakan hakikat komunikasi ialah proses penyampaian pikiran atau perencanaan atau perasaan seseorang (komunikator) kepada orang lain (komunikan). Pemikiran merupakan gagasan, informasi, opini yang muncul dari benaknya. Perasaan berupa keyakinan, kepastian, keraguan, kekhawatiran, kemarahan, kebencian dari lubuk hati (Bungin, 2007:31).

Effendy (1999:32), menjelaskan strategi Komunikasi merupakan panduan perencanaan komunikasi dengan manajemen komunikasi untuk mencapai tujuan yang ditentukan. Dalam strategi komunikasi mampu menunjukan bagaimana operasionalnya secara praktik harus dilakukan melalui pendekatan berbeda beda melihat kondisi dan situasi. Sedangkan Arifin mendefinisikan strategi komunikasi sebagai suatu perencanaan komunikasi yang meliputi strategi dan manajemen perencanaan strategi menyangkut tindakan apa yang dilakukan sedangkan perencanaan meliputi bagaimana hal hal yang terjadi (Arifin, 1994:10).

Dalam menyusun strategi komunikasi tidaklah mudah karena adanya aktivitas komunikasi yang kompleks. Oleh karena itu, sehubungan dengan hal tersebut, maka model komunikasi yang bisa kita kaitkan, dengan strategi komunikasi adalah model atau formula yang dikemukakan oleh Lasswell (2009:10, Ebook) yaitu : who, says what, in which channel, to whom, with what effect (siapa, berkata apa, melalui saluran apa, kepada siapa, dan bagaimana efeknya). Model ini termasuk model mekanistis, di mana menurut perspektif mekanistis, komunikasi secara umum memiliki 5 (lima) unsur, yaitu: a. Komunikator atau sumber, b. (pesan) c. Komunikan atau sasaran atau khalayak d. Media atau saluran, dan e. Efek atau balikan.

\section{METODE}

Metode penelitian ini yaitu kualitatif dengan pendekatan studi kasus. Dengan fokus penelitian mengenai strategi sosialisasi kebijakan penderekan oleh Suku Dinas Perhubungan Jakarta Barat. Pengumpulan data yang dilakukan melalui observasi 
langsung ke lapangan, wawancara dengan Plt. Kepala Seksi Operasional dan Pengawas Suku Dinas Perhubungan Jakarta Barat.yang menjadi Narasumber dari penelitian ini serta adanya studi dokumentasi yang dilakukan. Narasumber dalam penelitian ini adalah Plt. Kepala Seksi Operasional dan Pengawas Suku Dinas Perhubungan Jakarta Barat. Data yang diperoleh kemudian dianalisis melalui tahap-tahap deskriptif, analisis tema dan penonjolan.

Paradigma dalam penelitian ini menggunakan paradigma konstruktivisme. Di mana peneliti untuk melihat realitas dalam strategi komunikasi dalam mensosialisasikan Peraturan Daerah No. 5 Tahun 2014 berdasarkan dari yang dikonstruksikan dilapangan atau berdasarkan hasil observasi lapangan. Subjek Penelitian adalah Bagian Operasional Dinas Perhubungan Kota Administrasi Jakarta Barat, yang dipilih secara purposif karena dengan pertimbangan mereka adalah lembaga yang mampu menjelaskan bagaimana dan mengapa atas strategi komunikasi dalam mensosialisasikan Perda No. 5 Tahun 2014 khususnya pada penderekan kendaraan roda empat ketika parkir di badan jalan. Objek penelitian ini adalah strategi komunikasi yang diterapkan Dinas Perhubungan Kota Administrasi Jakarta Barat dalam mensosialisasikan Perda No. 5 Tahun 2014 tentang transportasi khususnya pada penderekan kendaraan roda empat.

\section{HASIL DAN PEMBAHASAN}

Di dalam Peraturan Daerah Jakarta Nomor 5 Tahun 2014 mengenai transportasi, di dalam pasal BAB 1 Pasal 1 disebutkan adanya definisi parkir, berhenti, marka jalan, peraturan mengenai parkir yang seyogyanya masyarakat dapat paham sebagai pengguna jalan. Apabila terdapat kendaraan roda empat yang memarkir kendaraannya dibahu jalan atau di marka jalan, petugas berhak memindahkan kendaraan tersebut ke kecamatan terdekat atau tempat yang sudah Dinas Perhubungan Kota Administrasi Jakarta Barat dan pengendara tersebut harus membayar retribusi penderekan sebesar Rp.500.000,- ke negara.

Penderekan merupakan salah satu peraturan daerah yang dilakukan bukan dengan unsur pemaksaan tapi pemindahan kendaraan saja ke kecamatan atau tempat yang sudah Dinas Perhubungan sediakan. Penderekan yang dilakukan oleh Suku Dinas Perhubungan Kota Administrasi Jakarta Barat tidak ada denda yang harus dibayarkan ke petugas namun yang ada adalah retrubusi penderekan. Retribusi penderekan sudah diatur di dalam Perda No. 3 Tahun 2012 (Lamudin, Pengawas
Suku Dinas Perhubungan Kota Administrasi Jakarta Barat).

Petugas Dinas Perhubungan melakukan penderekan berdasarkan peraturan daerah DKI Jakarta Nomor 5 Tahun 2014, penderekan itu dilakukan bukan dengan unsur pemaksaan tapi adanya pemindahan kendaraan saja ke parkir resmi atau ke tempat penyimpanan kendaraan yang disediakan oleh Pemerintah Daerah. Strategi sosialisasi kebijakan penderekan oleh Suku Dinas Perhubungan Jakarta Barat dapat dilakukan dengan cara hal-hal substansial yang diperkirakan akan mempengaruhi pelaksanaan sosialisasi. Hal-hal tersebut menyangkut 1). Perencanaan strategi sosialisasi kebijakan penderekan yang dilakukan oleh Suku Dinas Perhubungan Kota Administrasi Jakarta Barat.; 2). Sumber strategi sosialisasi kebijakan penderekan melalui media sosial.; 3). Hambatan strategi sosialisasi kebijakan penderekan melalui media sosial.; dan 4) Gambaran audien sosialisasi kebijakan penderekan melalui media sosial.

\section{Perencanaan Strategi Sosialisasi Kebijakan Penderekan}

Pada dasarnya perencanaan strategi sosialisasi kebijakan penderekan Suku Dinas Perhubungan Kota Administrasi Jakarta Barat berasal dari kebijakan Gubernur DKI Jakarta periode 20122014 yaitu Bapak Basuki Tjahaja Purnama. Dengan adanya Perda DKI Jakarta Nomor 5 Tahun 2014 bermaksud untuk meringankan adanya kemacetan yang dialami di Provinsi DKI Jakarta. Dengan adanya Perda DKI Jakarta Nomor 5 Tahun 2014 yang mengatur mengenai transportasi diharapkan masyarakat tetap patuh terhadap peraturan yang berlaku. Selain itu, adanya peraturan daerah tersebut dibuat karena pengawas dalam jumlah yang masuk semakin meningkat setiap tahunnya, yang menyebabkan padatnya jalan raya ataupun jalanan utama. Namun tidak berimbang dengan adanya pelebaran jalan di DKI Jakarta.

Karena bisa kita amati secara langsung bahwa di Jakarta sendiri belum ada penambahan atau pelebaran jalan baru yang signifikan untuk menyeimbangkan kendaraan yang masuk setiap tahunnya (Afandi, Plt Kasiop Suku Dinas Perhubungan Jakarta Barat). Pelebaran jalan di Joglo, Jakarta Barat sempat merangkak bertahuntahun, namun pekerjaan tersebut sudah dilakukan pelebaran jalan. Permasalahan dari ruas dan tata ruang kota DKI Jakarta yang tidak memungkinkan dibandingkan dengan volume kendaraan setiap harinya mengakibatkan adanya kemacetan yang setiap hari kita lihat seksama. 
Selain itu, Peraturan Daerah ini lahir dikarenakan banyaknya pengendara yang punya mobil tapi tidak mempunyai garasi dirumahnya. Mayoritas masyarakat DKI Jakarta ialah seseorang pendatang dari luar yang memiliki lahan rumahnya yang minim tanah mengakibatkan tidak ada ruang untuk menaruh kendaraannya di garasi. Kantung parkir pun masih belum berjalan efektif sehingga masih banyak masyarakat yang parkir sembarangan. Masyarakat yang parkir di jalan tentu akan mengganggu pengguna mengeksekusi perencanaan komunikasi.

Namun dalam mengidentifikasi isu mengenai transportasi jumlah kendaraan roda dua dan roda empat mengalami kenaikan yang signifikan terlihat pada tabel di bawah ini:

Dari jumlah kendaraan bermotor menurut jenisnya terlihat dampat dari arus lalu lintas di DKI Jakarta semakin padat dan rawan mengundang kemacetan lalu lintas diakibatkn adanya parkir

Tabel 3.

Jumlah Kendaraan pada Tahun 2009-2017

\begin{tabular}{|c|c|c|c|c|c|c|c|c|c|}
\hline $\begin{array}{c}\text { Jenis } \\
\text { Kendaraan } \\
\text { bermotor }\end{array}$ & 2009 & 2010 & 2011 & 2012 & 2013 & 2014 & 2015 & 2016 & 2017 \\
\hline $\begin{array}{c}\text { Mobil } \\
\text { Penumpang }\end{array}$ & 7910407 & 8891041 & 9548866 & 10432259 & 11484514 & 12599038 & 13480973 & 14580666 & 15493068 \\
\hline Mobil Bis & 2160973 & 2250109 & 2254406 & 2273821 & 2286309 & 2398846 & 2420917 & 2486898 & 2509258 \\
\hline Mobil Barang & 4498171 & 4687789 & 4958738 & 5286061 & 5615494 & 6235136 & 6611028 & 7063433 & 7523550 \\
\hline $\begin{array}{c}\text { Sepeda } \\
\text { Motor }\end{array}$ & 52767093 & 61078188 & 68839341 & 76381183 & 84732652 & 92976240 & 98881267 & 105150082 & 113030793 \\
\hline Jumlah & 67336644 & 76907127 & 85601351 & 94373324 & 104118969 & 114209260 & 121394185 & 129281079 & 138556669 \\
\hline
\end{tabular}

Sumber: data diolah oleh penulis

jalan lain, apalagi saat rush hour (jam sibuk) (Afandi, Plt Kasiop Suku Dinas Perhubungan Jakarta Barat).

Dengan adanya perencanaan strategi sosialisasi tidak terlepas tugas dan tanggung jawab Dinas Perhubungan Tingkat Provinsi sampai tingkat kecamatan untuk mampu mewujudkan wilayahnya bebas dari kemacetan dan parkir liar. Adanya sosialisasi pengenai adanya penderekan yang dilakukan oleh Suku Dinas Perhubungan DKI Jakarta tidak terlepas dari adanya peranan manajemen komunikasi di dalamnya, sehingga terciptanya adanya perencanaan tersebut hingga terjadi tindakan penderekaan terhadap kendaraan yang parkir di bahu jalan.

Manajemen komunikasi sendiri, merujuk Baker dalam Claywood (1997:461-463) mengatakan manajemen komunikasi pemerintah secara taktikal meliputi tiga hal: Pertama, identifikasi isu secara fokus menyangkut kebijakan atau program pemerintah. Kedua, menyusun perencanaan komunikasi mengacu pada isu yang sudah dikemas sesuai karakteristik yang diinginkan. Ketiga, liar, khususnya di wilayah Jakarta Barat. Merujuk, Anggiat Banjar Nahor terdapat titik yang menjadi konsentrasi Dinas Perhubungan yang sudah menjadi daerah yang dipetakan menjadi daerah rawan mobil rawan parkir di bahu jalan antara lain: Pasar Sentra di Cengkareng, Jalan S Parman dari Taman Anggrek sampai Grogol, Kalijodo sampai Season City, Jalan Gajah Mada. Jalan Panjang, Jalan Bali di Palmerah, Pesanggrahan, dan Terminal Kalideres (Arief Ikhsanudin, detiknews, diakses https://news.detik. com/berita/d-3681801/ada-8-lokasi-rawan-parkirliar-di-jakbar-kebanyakan-di-perumahan pada 10 Februari 2019 pukul 12.21 wib).

Adanya pemetaan wilayah yang dilakukan oleh Suku Dinas Perhubungan Kota Administrasi Jakarta Barat. Dilakukan untuk melakukan penyusunan perencanaan komunikasi mengacu pada isu kemacetan dan parkir liar yang sudah dikemas sesuai karakteristik yang diinginkan dari lembaga tersebut. Penyusunan perencanaan komunikasi, dilakukan dengan adanya sosialisasi ke masyarakat yaitu dilakukan dengan cara memasang banner sebagai alat informasi ke masyarakat. Pemasangan 
banner dilakukan di titik titik kecamatan maupun kelurahan. Di mana Dinas Perhubungan memiliki Satuan Pelaksana Perhubungan Kecamatan yang bertugas untuk melayanai pengaduan masyarakat tingkat kelurahan maupun kecamatan. Biasanya pemasangan banner ini dilakukan di titik titik wilayah yang banyak terjadi parkir liar (Afandi, Plt Kasiop Suku Dinas Perhubungan Jakarta Barat).

Sistem sosialisasipun dilakukan ke masyarakat yaitu adanya sistem CRM agar masyarakat lebih mudah mengakses dalam membuat laporan ke instansi terkait dengan adanya adanya kejadian parkir liar dan kemacetan di wilayah Jakarta Barat. Agar terlihat lebih humanis dan mudah memverifikasi data laporan yang diterima dari masyarakat setiap harinya. Laporan yang diterima setiap harinya ditindak lanjuti kasusnya sampai terselesainya laporan tersebut (Lamudin, Pengawas Suku Dinas Perhubungan Kota Administrasi Jakarta Barat).

\section{Sumber Strategi Sosialisasi Kebijakan Penderekan}

Sumber strategi adanya sosialisasi kebijakan penderekan yang dilakukan oleh Suku Dinas Hubungan Jakarta Barat, beranjak karena adanya maraknya pengaduan masyarakat mengenai parkir liar yang menyebabkan adanya kemacetan di DKI Jakarta. Pemerintah provinsi membuat kebijakan yang berlandaskan hukum mengenai Parkir Sembarangan di bahu jalan. Merujuk pada PERDA NOMOR 5 TAHUN 2014 TENTANG TRANSPORTASI, di dalam pasal 95 ayat (1) berisi "Dalam rangka penyelenggaraan urusan Transportasi di daerah, Pemerintah Daerah dapat melaksanakan penindakan atas pelanggaran Lalu Lintas dan Angkutan Jalan tertentu oleh Penyidik Pegawai Negeri Sipil di Dinas".

Penindakan sebagaimana dimaksud pada ayat (1) dilakukan terhadap pengguna Jalan yang melakukan pelanggaran sebagai berikut :

a. Memasuki lajur atau jalur khusus Angkutan umum massal berbasis Jalan;

b. Memarkir Kendaraan di ruang milik Jalan yang bukan fasilitas Parkir;

c. Menyalahgunakan fungsi fasilitas Pejalan Kaki;

d. Melanggar ketentuan pada kawasan pengendalian Lalu Lintas;

e. Menggunakan Kendaraan Bermotor Perseorangan pada kawasan Hari Bebas Kendaraan Bermotor (Car Free Day);

f. Menunggu, menaikkan, dan/atau menurunkan penumpang Kendaraan Bermotor Umum tidak pada tempat pemberhentian yang telah ditetapkan;

g. Menggunakan Kendaraan Bermotor pada lajur sepeda;

h. Melanggar kewajiban Pengemudi Kendaraan Bermotor Umum sebagaimana dimaksud dalam Pasal 92 ayat (2); dan

i. Pelanggaran terhadap pemenuhan persyaratan teknis dan laik Jalan serta aspek keselamatan Kendaraan Bermotor Umum.

Terhadap Kendaraan Bermotor yang berhenti dan/atau Parkir bukan pada fasilitas Parkir yang ditetapkan, dapat dilakukan tindakan: Pertama, penguncian ban kendaraan; Kedua, pemindahan kendaraan dengan cara penderekan ke tempat Parkir resmi atau ke tempat penyimpanan kendaraan yang disediakan oleh Pemerintah Daerah; dan/atau; Ketiga, pencabutan pentil ban.

Adanya peraturan tersebut, seyogyanya membuat efek jera masyarakat agar tidak melakukan parkir liar atau parkir di badan jalan. Adapun dampak parkir liar yang dilakukan di badan jalan adalah terjadinya penyempitan ruang jalan lalu lintas, berdampak pada pengurangan kecepatan laju kendaraan dan mengakibatkan kemacetan sehingga akan merugikan banyak pengguna jalan (Dinas Perhubungan DKI JAKARTA, https://dishub.jakarta.go.id/ketentuan-parkir/ pada tanggal 13 Februari 2019 pukul 13.28 wib)

Sanksi yang diterapkan untuk memberikan efek jera bagi pelanggar parkir yang telah memarkir kendaraannya di badan jalan adalah dengan menerapkan 2 sanksi, diantaranya : Pertama, Dikenakan denda maksimal sesuai dengan UU No. 22 Tahun 2009 tentang Lalu Lintas dan Angkutan jalan, sebesar Rp. 500.000,- yang diberikan oleh kepolisian dengen menerapkan tilangan slip biru, sehingga pelanggar harus membayarkan dendanya melalui BANK BRI. Kedua, Penderekan kendaraan yang dilakukan oleh petugas Dinas Perhubungan Provinsi DKI Jakarta, sesuai dengan Perda No. 5 Tahun 2012 tentang Perparkiran, disebutkan kendaraan yang parkir dibadan jalan dan mengganggu arus lalu lintas dapat dipindahkan atau diderek dan biaya retribusi penderekan menjadi tanggung jawab pelanggar, yang besarannya di tetapkan di Perda No. 3 Tahun 2012. Retribusi Daerah yaitu biaya penderekan dan penyimpanan kendaraan yang diderek karena parkir sembarangan sebesar Rp. 500.000,-/hari/kendaraan, yang 
pembayarannya disetorkan langsung ke BANK DKI (Afandi, Plt Kasiop Suku Dinas Perhubungan Jakarta Barat).

Adapun proses pembayaran retribusi penderekan akibat melanggar rambu larangan parkir, terlihat pada gambar di bawah ini :

\section{Gambar 2.}

Proses Pembayaran Retribusi Penderekan Akibat Melanggar Rambu Larangan Parkir

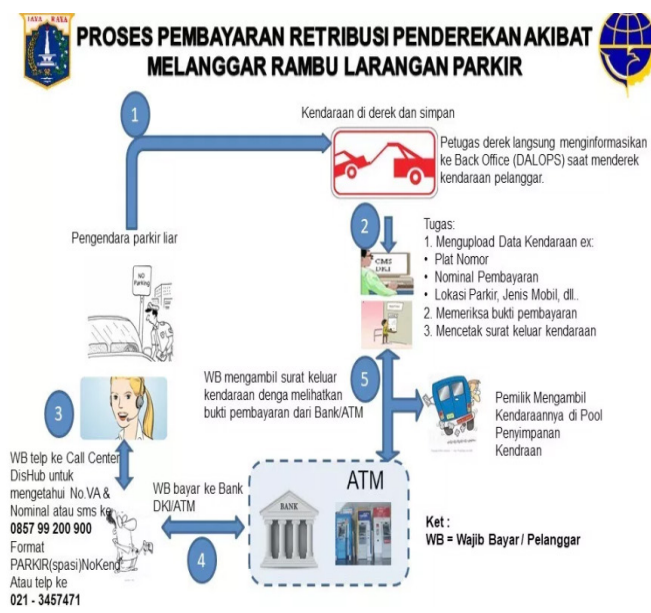

Sumber: Dinas Perhubungan DKI Jakarta

Semua proses retribusi penderekan harus melalui Virtual Account yang dikeluarkan oleh sistem Dinas Perhubungan DKI Jakarta. Adapun Proses Pembuatan Virtual Account terlihat pada gambar di bawah ini :

\section{Gambar 3.}

\section{Proses Pembuatan Virtual Account}

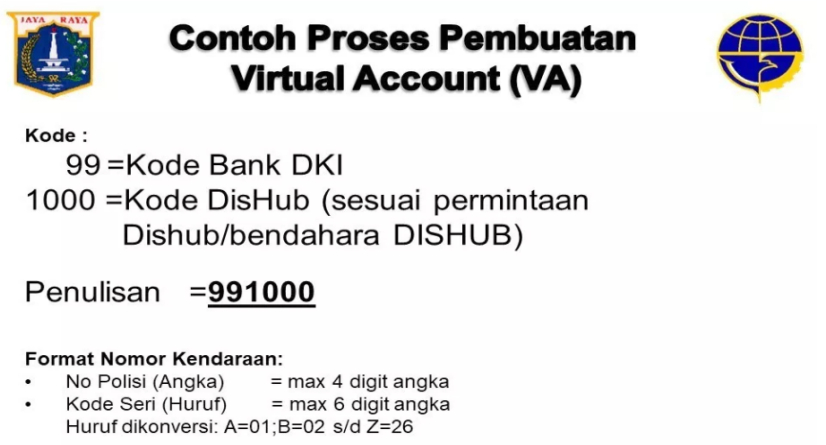

Sumber: Dinas Perhubungan DKI Jakarta

\section{Hambatan Strategi Sosialisasi Kebijakan Penderekan}

Masalah penderekan yang paling umum dirasakan masyarakat adalah ketika siapapun pengendara yang kendaraannya diderek pasti akan marah dan tidak terima. Pelanggaran yang dilakukan oleh pengendara kendaraan roda empat tidak langsung ditindak oleh Suku Dinas Perhubungan Kota Administrasi Jakarta Barat namun diberikan pengarahan ketika masih ada orang tersebut di dalam kendaraan.

Adanya retribusi penderekan yang harus dibayar oleh pengendara ketika parkir dibahu jalan seyogyanya bersifat memberikan efek jera ke masyarakat agar tidak parkir liar atau parkir di bahu jalan walaupun ada atau tidaknya rambu lalu lintas dilarang parkir di sini.

Setelah terjadinya penderekan ini biasanya akan muncul kesadaran untuk tidak parkir sembarangan dan masyarakat akan lebih aware dengan rambu-rambu yang ada di jalan. Suku Dinas Perhubungan Kota Administrasi Jakarta Barat melakukan pembinaan agar masyarakat tahu tentang Peraturan Daerah Nomor 5 tahun 2014. Pembinaan sendiri bisa dilakukan secara berjenjang, tidak harus langsung bertemu pimpinan Suku Dinas Perhubungan terkait namun bisa diwakilkan oleh karyawan Suku Dinas Perhubungan Kota Administrasi Jakarta Barat lainnya (Afandi, Plt Kasiop Suku Dinas Perhubungan Jakarta Barat).

Setiap karyawan dibekali dengan SOP (Standar Operasional Prosedur) yang sebagaimana bisa menjelaskan secara detail mengenai penderekan dan mampu mencari solusi langsung yang terjadi dilapangan. Setiap adanya penindakan penderekan pasti ada penyebabnya seperti pelanggaran parkir yang belum dipahami oleh masyarakat kita.

Hambatan-hambatan yang sering dialami pada saat sosialisasi kebijakan penderekan yang dilakukan oleh Suku Dinas Hubungan Kota Administrasi Jakarta Barat, antara lain (Lamudin, Pengawas Suku Dinas Perhubungan Kota Administrasi Jakarta Barat) :

1. Belum banyak tenaga ahli yang ada terutama bidang IT dan komunikasi

2. Kurangnya skill dan informasi mengenai anggota Suku Dinas Hubungan Kota Administrasi Jakarta Barat

3. Rasa peduli yang kurang akibat dari parkir di bahu jalan

4. Rasa ingin tahu masyarakat yang masih rendah mengenai kebijakan penderekan yang dilakukan oleh Suku Dinas Hubungan Kota Administrasi Jakarta Barat

5. Tingkat kesadaran masyarakat masih rendah

6. Adanya kesalah pahaman persepsi masyarakat menegenai rambu-rambu lalu lintas

7. Kurangnya pemahaman dari anggota Suku Dinas Hubungan Kota Administrasi Jakarta 
Barat dalam mensosialisasikan Perda DKI Jakarta Nomor 5 Tahun 2014.

8. Rawannya anggota Suku Dinas Hubungan Kota Administrasi Jakarta Barat saat berada dilapangan seperti ada beberapa yang handphone dirampas oleh pelanggar.

\section{Gambaran Khalayak Sosialisasi Kebijakan Penderekan}

DKI Jakarta merupakan kota yang tingkat kemacetannya parah. Kendala yang sering dialami, pada saat lampu lalu lintas mati, ada saja pengendara main serobot, melawan arus dan trotoar yang berfungsi sebagai pejalan kaki, kini beralih fungsi untuk pedagang kaki lima atau tempat parkir liar kendaraan bermotor. Tidak hanya itu, bunyi klakson, krang kring krung merupakan hal biasa yang sering kita amati di lampu lalu lintas sedang merah. Semua ingin mendahului dan saling serobot, sampai perempatan jalan itu stagnan, mentok dan macet total, maka riuhlah bunyi klakson-klakson menjadi budaya dalam bertransportasi di Ibu Kota DKI Jakarta.

Permasalahan parkir yang belum memiliki solusi yang konkret dari pemerintah. Banyak kita jumpai di beberapa jalanan daerah dan wilayah di DKI Jakarta khususnya di Jakarta Barat seperti Glodok, Kembangan, Meruya, Kebon Jeruk, Rawa Buaya, Kali Deres, Cengkareng menjadi pusat kemacetan atas banyaknya parkir liar yang dilakukan oleh beberapa pengendara yang memarkirkan kendaraannya seperti mobil sembarangan.

Gambaran umum pengendara kendaraan roda empat yang mobilnya diderek oleh petugas Suku Dinas Perhubungan Jakarta Barat. Alasan pengguna kendaraan tersebut memarkir di bahu jalan dikarenakan sempitnya lahan parkir di Jakarta Barat yang dapat digunakan untuk parkir mobil. Dan jauhnya lahan parkir dengan toko tempat mereka mengirimkan barang ke ekspedisi. Selain itu, pengendara memarkir di bahu jalan dikarenakan kecapaian diakibatkan perjalanan jauh dari luar kota. Masyarakat tidak mengetahui adanya peraturan yang tidak memperbolehkan memarkir kendaraannya di salah satu jalan dikarenakan tidak ada rambu di larang parkir di sini. Yang mengakibatkan kendaraan tersebut diderek dan dipindahkan ke kantor Suku Dinas Perhubungan Jakarta Barat. Sesampainya di sini, masyarakat harus membayar uang retribusi penderekan sebesar Rp.500.000,- dengan kelipatan setiap harinya.
Merujuk informasi Lamudin (Pengawas Suku Dinas Perhubungan Kota Administrasi Jakarta Barat), mayoritas masyarakat yang terkena penderekan parkir di bahu jalan bukan masyarakat Jakarta Barat melainkan masyarakat dari luar kota seperti Bekasi, Tangerang, Bogor dan sekitarnya. Peneliti menilai, sosialisasi penderekan Suku Dinas Perhubungan Kota Administrasi Jakarta Barat melalui Peraturan Daerah No. 5 Tahun 2014 tentang Transportasi harus diperluas jangkauannya dan sistem koordinasi ke masing masing wilayah Suku Dinas Perhubungan lainnya. dikarenakan setiap kendaraan yang parkir memarkir kendaraannya dibahu jalan atau di marka jalan, petugas berhak memindahkan kendaraan tersebut ke kecamatan terdekat atau tempat yang sudah Dinas Perhubungan Kota Administrasi Jakarta Barat dan pengendara tersebut harus membayar retribusi penderekan sebesar Rp.500.000,- ke negara.

\section{SIMPULAN}

Adanya strategi sosialisasi kebijakan penderekan oleh Suku Dinas Perhubungan Kota Administrasi Jakarta Barat, didasarkan pada sumber strategi sosialisasi berasal dari Peraturan Daerah Nomor 5 Tahun 2014. Di mana dalam peraturan ini membahas tentang transportasi. Sasaran dari sosialisasi kebijakan ini adalah masyarakat DKI Jakarta khususnya di wilayah Jakarta Barat agar masyarakat paham mengenai kebijakan penderekan Suku Dinas Perhubungan Kota Administrasi Jakarta Barat.

Penderekan merupakan salah satu peraturan daerah yang dilakukan bukan dengan unsur pemaksaan tapi pemindahan kendaraan dari badan jalan ke kecamatan atau tempat yang sudah Dinas Perhubungan sediakan. Serta dalam pasal BAB 1 Pasal 1 disebutkan adanya definisi parkir, berhenti, marka jalan, peraturan mengenai parkir yang seyogyanya masyarakat dapat paham sebagai pengguna jalan.

Komunikator dalam sosialisasi kebijakan penderekan kendaraan yang dilakukan oleh Suku Dinas Perhubungan Kota Administrasi Jakarta Barat ialah semua jajaran operasional Suku Dinas Perhubungan Kota Administrasi Jakarta Barat yang terdiri dari berbagai unsur yang bekerja sesuai dengan bidang yang ditanganinya dan jenis informasi yang disampaikan. Dengan kemampuan itu, terlihatlah perencanaan dari strategi sosialisasi 
kebijakan ini. Mulai dari planning, sumber, hambatan dan gambaran umum masyarakat Jakarta Barat.

\section{DAFTAR PUSTAKA}

Ardiansyah, N. (2018). https://jakarta.tribunnews. com/2018/11/23/trotoar-depan-kejaksaannegeri-jakarta-barat-digunakan-oknumjadilahan-parkir-liar?page=3).

Arifin, A. (1994). Strategi Komunikasi, Bandung: CV Amrico.

Asosiasi Pengguna Jasa Internet. (2017), Website: https://apjii.or.id.

Badan Pusat Statistik. (2018). Website: https://www. bps.go.id/linkTableDinamis/view/id/1133.

Bungin, B. (2007). Analisis Penelitian Kualitatif. Bandung: PT. Rajawali Pres.

Daft, R. L. ( 2010). Era Baru Manajemen. Jakarta: Salemba Empat.

Dinas Perhubungan DKI JAKARTA, https://dishub. jakarta.go.id/ketentuan-parkir/

Effendy, O. U. (1999). Ilmu Komunikasi Teori dan Praktek. Bandung: Remaja Rosdakarya.

Fachrudin, A. (2014). Strategi Program Tayangan Infotainment di RCTI. Jurnal Visi Komunikasi Volume 13, No. 01, Mei 2014.

Ikhsanuddin (2017). https://news.detik.com/ berita/d-3681801/ada-8-lokasi-rawan-parkirliar-di-jakbar-kebanyakan-di-perumahan.

Indarto. J. M. (2012). Manajemen Komunikasi Pemerintahan Dalam Kebijakan Transparansi Informasi (Studi Evaluasi Komunikasi Keterbukaan Informasi Publik Pada Kementerian Komunikasi dan Informatika), Tesis, Fakultas IImu Sosial dan IImu Komunikasi Program Studi Ilmu Komunikasi.

Lasswell, D. H. (2009). Structure an Function of Communication in Societ dalam. Wilbur Schramm. (Ed), Ebook.

Lamudin. (2019, Januari 21). S.Pd. (V. U. Subiakto, Interviewer).

Lembaga Penelitian Universitas Mercu Buana. (2016). Rencana Induk Penelitian Universitas Mercu Buana Tahun 2016-2020.

Novrisal, A. (2019, 13 Februari 7). (V. U. Subiakto, Interviewer).

Peraturan Daerah Nomor 5 Tahun 2014.

Quinn, B. J. (1980). Strategies for change: logical incrementalism Irwin series in management and the behavioral sciences, R.D. Irwin. US: The University of Michigan, Ebook.

Rangkuti, F. (2004). Analisis SWOT Teknik Membedah Kasus Bisnis. Jakarta: PT. Gramedia.

Sarastuti, D. (2017). Strategi Komunikasi Pemasaran Online Produk Busana Muslim Queenova. Jurnal Visi Komunikasi/ Nolume 16, No.01, Mei 2017: 71 - 90.

Soekanto, S. (1989). Sosiologi Suatu Pengantar. Jakarta: Raja Grafindo Persada.

Undang-Undang Nomor 22 Tahun 2009.

Zakiyudin, A. (2016). Manajemen Bisnis, Jakarta: Mitra Wacana Media. 